\title{
Nutritive value of fibrous ingredients fed to pigs in the Democratic Republic of Congo measured using an in vitro technique
}

\author{
Bienvenu Kambashi, ${ }^{1,2 \dagger}$, Christelle Boudry ${ }^{2}$, Pascale Picron $^{2}$, Honoré Kiatoko ${ }^{1}$, \\ Maximilien Muland ${ }^{3}$, André Théwis ${ }^{2}$ and Jérôme Bindelle ${ }^{2+}$ \\ ${ }^{1}$ University of Kinshasa, Department of Animal Production, Democratic Republic of Congo; ${ }^{2}$ University of Liège, Gembloux Agro-Bio Tech, Animal Science Unit, \\ Belgium; ${ }^{3}$ Centre agronomique et vétérinaire tropical de Kinshasa, Democratic Republic of Congo
}

\section{Introduction}

Incorporation of forages in the diets can improve the economics of smallholder pig production in tropical countries. However, the information on the nutritive value of fibrous crop by-products and forages species used as ingredients in pig diets is scarce. The present work aimed at measuring the chemical composition and the nutritive value using an in vitro model of the pig gastro-intestinal tract of 21 ingredients used by farmers in the province of Bas-Congo (D.R. Congo).

\section{Materials and Methods}

Seven grasses and 14 dicot samples were analyzed for DM, OM, crude protein, crude fat, fiber and mineral content. The samples were hydrolyzed using porcine pepsin $\left(\mathrm{pH} 2,39^{\circ} \mathrm{C}, 2 \mathrm{~h}\right)$ and pancreatin $\left(\mathrm{pH} 6.8,39^{\circ} \mathrm{C}, 4 \mathrm{~h}\right)$ to mimic digestion in the stomach and the small intestine. The hydrolyzed residues were subsequently fermented in an in vitro gas test with a pig fecal inoculum (Bindelle et al., 2007) to simulate fermentation in the large intestine. Hydrolyzed ingredients were analyzed for protein in order to estimate digestible protein content. Hydrolysis of the different ingredients was compared using ANOVA, as well as the fermentation kinetics after mathematical modeling (Groot et al., 1996).

Table 1 In vitro dry matter digestibility (IVDMD), in vitro digestible protein (DP), Ca, P contents, final gas production (A) and rate of gas production of the hydrolyzed residues (Rmax)

\begin{tabular}{|c|c|c|c|c|c|c|c|}
\hline Ingredients & Part & $\begin{array}{l}\text { IVDMD } \\
(-)\end{array}$ & $\begin{array}{c}D P \\
(\mathrm{~g} / \mathrm{kg})\end{array}$ & $\begin{array}{c}\mathrm{Ca} \\
(\mathrm{g} / \mathrm{kg})\end{array}$ & $\begin{array}{c}P \\
(\mathrm{~g} / \mathrm{kg})\end{array}$ & $\begin{array}{c}\text { A } \\
(\mathrm{ml} / \mathrm{g})\end{array}$ & $\begin{array}{l}\text { Rmax } \\
\text { (ml/g.h) }\end{array}$ \\
\hline Acacia mangium & leaves & 0.31 & 32 & 6.8 & 1.2 & 39 & 1 \\
\hline Amaranthus hybridus spp & plant & 0.56 & 188 & 22.9 & 7.8 & 215 & 18 \\
\hline Brachiaria ruziziensis & plant & 0.34 & 86 & 6.2 & 2.1 & 235 & 8 \\
\hline Cajanus cajan & leaves & 0.32 & 34 & 7.4 & 1.6 & 53 & 2 \\
\hline Calopogonium muconoides & plant & 0.37 & 144 & 17.4 & 1.8 & 136 & 12 \\
\hline Centrosema pubescens & plant & 0.42 & 173 & 15.8 & 2.0 & 119 & 5 \\
\hline Eichornia crassipes & plant & 0.31 & 59 & 10.8 & 1.4 & 92 & 3 \\
\hline Ipomea batatas & leaves & 0.45 & 144 & 15.7 & 3.6 & 203 & 17 \\
\hline Leucaena leucocephala & leaves & 0.37 & 103 & 24.2 & 1.2 & 85 & 4 \\
\hline Manihot esculenta & leaves & 0.43 & 176 & 20.7 & 4.1 & 169 & 15 \\
\hline Moringa oleifera & leaves & 0.43 & 179 & 28.3 & 3.3 & 168 & 13 \\
\hline Mucuna pruriens & plant & 0.46 & 187 & 26.3 & 2.0 & 155 & 9 \\
\hline Panicum maximun wild cultivar & plant & 0.29 & 101 & 7.4 & 2.8 & 170 & 5 \\
\hline Panicum maximun var. T58 & plant & 0.25 & 77 & 7.4 & 3.2 & 196 & 6 \\
\hline Pennisetum purpureum & plant & 0.30 & 68 & 3.6 & 1.5 & 207 & 7 \\
\hline Psophocarpus scandens & plant & 0.49 & 247 & 14.5 & 3.4 & 155 & 8 \\
\hline Pueraria javanica & plant & 0.38 & 156 & 10.5 & 2.7 & 122 & 8 \\
\hline Saccharum offinarum & leaves & 0.42 & 30 & 4.6 & 0.9 & 88 & 3 \\
\hline Stylosanthes guianensis & plant & 0.25 & 101 & 21.9 & 4.8 & 173 & 11 \\
\hline Trypsacum laxum & plant & 0.27 & 60 & 4.0 & 2.0 & 183 & 5 \\
\hline Vigna unguiculata & plant & 0.48 & 221 & 37.0 & 3.4 & 183 & 12 \\
\hline$P$-value & & $<0.001$ & $\mathrm{~N} / \mathrm{A}$ & $\mathrm{N} / \mathrm{A}$ & $\mathrm{N} / \mathrm{A}$ & $<0.001$ & $<0.001$ \\
\hline
\end{tabular}

†E-mail: bkambashi@gmail.com; jerome.bindelle@ulg.ac.be 


\title{
Results and discussion
}

The results from chemical analyses and in vitro digestibility summarized in Table 1 show as expected a generally lower nutritive value of grasses compared to dicots and especially legume species. With poor enzymatic digestibility and fermentability, $A$. mangium leaves must be advised against for use by farmers. Crop residues of $A$. hybridus, I. batatas, M. esculenta, P. scandens and V. unguiculata and herbaceous and woody forage species such as $M$. pruriens and $M$. oleifera, respectively, look promising. They combine high digestible energy, assessed through IVDMD, A and Rmax, high DP contents with high levels of minerals. Nevertheless, future work should assess the maximum levels of incorporation in diets as most of these ingredients contain anti-nutritional components reducing voluntary intake, digestibility or both.

\section{Acknowledgements}

The authors gratefully acknowledge WBI and DGARNE (Belgium) for their funding to the CAVTK project.

\author{
References \\ Bindelle J, Buldgen A, Boudry C and Leterme P 2007. . Animal Feed Science and Technology 132, 111-122. \\ Groot JCJ, Cone J, Williams BA, Debersaques FD and Lantinga EA 1996. . Animal Feed Science and Technology 64, 77-89.
}

doi:10.1017/S2040470010000518

\section{Digestibility, metabolic utilization and nutritional value of Cassia tora (Linn.) leaf meal incorporated in indigenous Senegal chickens diets}

\author{
S. B. Ayssiwede ${ }^{1 \dagger}$, C. Chrysostome ${ }^{2}$, W. Ossebi ${ }^{1}$, A. Dieng ${ }^{3}$, J. L. Hornick ${ }^{4}$ and A. Missohou ${ }^{1}$ \\ ${ }^{1}$ Laboratory of Animal nutrition (LANA), EISMV Dakar (Senegal); ${ }^{2}$ Faculty of Agronomical Science, University of Abomey-Calavi; ${ }^{3}$ Laboratory of Bromatology, \\ Superior National School of Agriculture, Thiès (Sénégal); ${ }^{4}$ Animal Nutrition Service, Faculty of Veterinarian Medicine of Liege University (Belgium)
}

\section{Introduction}

Indigenous chicken production is confronted with various constraints in which feed is a major challenge. Besides the lack of dietary supplement, village chickens face quantitative and qualitative feed shortages particularly in a poor agricultural or household residue environment. Moreover, because of the increasingly cost of common protein ingredients (groundnut cake, soybean or fish meal) traditional stockholders often have little access to such resources. However, studies carried out on legumes reported that the leaves of Cassia tora, are rich in protein, essential amino acids and minerals. The prospect thus arises of using Cassia tora leaf meal as a protein ingredient source in Senegal indigenous chickens diets. This study was undertaken to determine their nutrient utilization and nutritional value.

\section{Materials and methods}

Cassia tora leaves were collected mainly in the region of Thies, $70 \mathrm{~km}$ from Dakar. They were dried for $1-2$ days and processed into meal using a grinder mesh $4 \mathrm{~mm}$ in diameter. The leaf meal and the other common ingredients (yellow maize, white sorghum, millet, wheat bran, fish meal, and groundnut cake) were analysed for their composition using AFNOR technical. These ingredients were used to formulate four isonutrient calculated dietary treatments $\left(\mathrm{CT}_{0}, \mathrm{CT}_{5}, \mathrm{CT}_{10}\right.$ and $\left.\mathrm{CT}_{15}\right)$ containing respectively $0,5,10$ and $15 \%$ of cassia tora leaf meal. Experiments were undertaken from $15^{\text {th }}$ to $27^{\text {th }}$, November 2009. Twenty adult indigenous chickens with an average weight of $1.16 \mathrm{~kg}$ were raised in metabolic cages and allocated into four dietary treatments groups of five birds each. During the experiment feed offered and fresh excreta collected were weighted daily for six days. The droppings were oven-dried at $60^{\circ} \mathrm{C}$ and ground for nutrient analysis per bird. Daily feed intake (DFI) and average daily weight gain (ADWG) were calculated. Apparent coefficients of nutrient utilization (ACNU) were determined according to the following formula: $\mathrm{ACNU}=(\mathrm{NI}-\mathrm{NF}) \div \mathrm{NI}$, where NI was nutrient intake and NF nutrient excreted. Data were analysed at $5 \%$ level by variance analysis (ANOVA) completed with t-test when ANOVA showed significant difference.

\section{Results}

The Cassia tora leaf meal was relatively rich in protein $(27.44 \%$ DM), crude fiber (16.8\% DM), NDF (25.7\% DM) and ash (15.16\% DM), particularly calcium (3.13\%) and potassium (1.3\% DM). It contained respectively $3.82 \%$ DM, 36.77\% DM and $2050.47 \mathrm{kcal} / \mathrm{kg}$ DM of ether

\footnotetext{
† E-mail: s.ayssiwede@eismv.org
} 